\title{
PELATIHAN KONTROL DIRI UNTUK MENGURANGI KECENDERUNGAN INTERNET GAMING DISORDER PADA ANAK USIA SEKOLAH
}

\author{
Ria Fatma Ramadhani ${ }^{1}$, Iswinarti ${ }^{2}$, Uun Zulfiana ${ }^{3}$ \\ 1,2,3 Fakultas Psikologi, Universitas Muhammadiyah Malang \\ 1rfatmar19@gmail.com, ${ }^{2}$ iswinarti.psi@gmail.com, ${ }^{3}$ uun@umm.ac.id
}

\begin{abstract}
Abstrak. Pada zaman yang semakin canggih ini penggunaan gadget tidak terbatas pada kalangan orang dewasa saja melainkan anak-anak juga telah menggunakan gadget. Gadget digunakan untuk membantu memenuhi segala kebutuhan salah satunya adalah kebutuhan mencari hiburan dengan bermain game, yang dengan mudah bisa dimainkan dengan menggunakan internet. Penggunaan internet untuk bermain game secara terus menerus dan mengakibatkan dampak negatif bagi dirinya akan menyebabkan internet gaming disorder. Tingginya tingkat internet gaming disorder pada anak dapat diatasi, salah satunya dengan memberikan pelatihan kontrol diri. Penelitian ini bertujuan untuk memberikan pelatihan konrol diri sebagai metode eksperimen dalam mengurangi tingkat internet gaming disorder pada anak usia sekolah serta melihat seberapa besar pengaruh perlakuan pada tingkat internet gaming disorder. Penelitian ini merupakan penelitian eksperimen dengan desain control group pre-test post-test. Penelitian ini dilakukan pada 12 orang anak usia sekolah 9-11 tahun dengan menggunakan teknik purposive sampling yang terbagi menjadi 2 grup. Hasil penelitian menunjukkan adanya pengaruh signifikan pelatihan kontrol diri terhadap tingkat internet gaming disorder $(\mathrm{p}=0,04$ dimana nilai $\mathrm{p}$ $<$ 0,05). Dengan begitu, pelatihan kontrol diri dapat menurunkan internet gaming disorder pada anak usia sekolah.
\end{abstract}

Kata kunci: Internet Gaming Disorder, Pelatihan Kontrol Diri, Anak Usia Sekolah

Abstract. In this particular sophisticated era, the use of gadget is not limited only within the reach of the adults but also children for the sake of fulfilling many of the needs which one of it happened to be the need of entertainment through internet gaming. The use of internet for playing games continuously with its negative effect will lead to an Internet Gaming Disorder. High level of Internet Gaming Disorder can be overcome, one of it would be by giving a self-control training. This research aims to apply a self-control training as an experimental method to reduce the level of Internet Gaming Disorder in children as well as sighting at how much of an impact the intervention will be on the level of IGD. This research is experimental with control group pre-test post-test design. 12 children with the age of 9-11 will be chosen as participants through purposive sampling technique. The result of this research showed that there is a significant impact of a self-control training towards the level of igd $(p=0.04)$. With that being said, selfcontrol training is capable of reducing the level of igd in children.

Keyword: Internet Gaming Disorder, Self-control training, Schooler 
Perkembangan teknologi komunikasi dari tahun ke tahun sangatlah cepat, banyak gadget keluaran terbaru dengan piranti-piranti pendukungnya yang begitu canggih dan berbagai macam kelebihan yang ditawarkan tidak bisa dihindarkan oleh banyak kalangan masyarakat. Sudah menjadi hal yang umum bila masyarakat dihadapkan pada berbagai situasi yang membuat mereka untuk melek terhadap teknologi yang berkembang saat ini. Berawal dari kebutuhan untuk memenuhi kebutuhan komunikasi yang sederhana seperti pesan singkat serta pesan suara, namun saat ini alat-alat teknologi komunikasi menjadi multifungsi sebagai sarana atau media untuk memfasilitasi pembelajaran diluar kelas, hiburan portable, kegiatan jual-beli, atau hanya sekedar mencari informasi dengan menggunakan jaringan internet. Secara umum, anak-anak usia muda dari setiap kalangan memiliki peralatan berteknologi (gadget) dengan rentang jenis dan level yang berbeda. Terlebih untuk anak-anak usia sekolah yang menempatkan penggunaan teknologi sebagai salah satu prioritas utama dalam pemenuhan kebutuhan seperti proses pembelajaran dan pengerjaan tugas.

Anak usia sekolah bisa dikatakan masa kanak-kanak akhir yakni usia 6-12 tahun Pada masa ini anak mulai untuk meningkatkan kemampuan yang ada, mulai menguasi tanggung jawab dan proses berfikir yang lebih logis dan kritis (Santrock, 2011). Daya ingat anak bekembang semakin kuat, serta anak dapat membedakan mana yang terlihat oleh indra dan kenyataan sesungghunya serta mana yang bersifat sementara dan mana yang menetap anak tidak lagi berfikir dengan egosentris dan sudah mulai mampu menilai dari sudut orang lain.Anak juga akan mengembangkan ide kreatifnya dan keterampilannya, serta belajar mengenal tentang lingkungan yang lebih luas bukan hanya lingkungan keluarganya saja tetapi juga dari sekitarnya, seperti mulai mengenal media.

Kecenderungan untuk selalu mengggunakan media teknologi atau gadget adalah salah satu fenomena yang sangat pesat berkembang. Gadget memiliki banyak fungsi bagi penggunanya sehingga dinilai lebih memudahkan. Kemudahan itu juga yang membuat seluruh individu dari seluruh kategori usia sangat bergantung terhadap gadget terutama anak-anak dan remaja (Rohmah, 2017). Berbagai macam dampak bisa terjadi dari bergantungnya terhadap kemudahan yang ditawarkan bagi pengguna gadget, terutama dikalangan masyarakat pada usia anak-anak dan remaja. Banyak anak-anak yang diperbudak dengan yang namanya gadget. Anak-anak usia 9-12 tahun yang telah menggunakan gadget di kehidupan sehari-hari, baik untuk hiburan maupun berkomunikasi dengan orang lain. Penggunaan gadget ini pun banyak didukung oleh orang tua dilihat dari banyaknya jumlah anak yang memiliki gadgetnya sendiri. Akibatnya mayoritas anak banyak yang menghabiskan waktu luang untuk bermain dengan menggunakan gadget.

Pengenalan gadget terlalu dini pada anak dapat memberikan dampak positif maupun negatif. Hal ini dipengaruhi oleh beberapa faktor seperti frekuensi dan durasi pemakaian, serta pengawasan orang tua. Penggunaan gadget sebagai bahan dasar pembelajaran pada anak akan berdampak positif seperti meningkatkan kreativitas dan daya pikir anak. Begitupula sebaliknya, bila pengawasan dari orang tua kurang dan tidak ada upaya yang tegas dalam pembagian waktu pemakaian gadget pada anak akan dapat menimbulkan sisi negatif. Dampak negatif tersebut mampu menyebabkan seseorang menjadi pemalu, kurang percaya diri, menyendiri dan keras kepala. Seperti yang dipaparkan oleh Iswidharmanjaya (2011), salah satu dampak dari penggunaan gadget adalah anak menjadi 
pribadi yang cenderung menyendiri. Dengan begitu anak akan merasa asing dan kurang peka terhadap lingkungan disekitarnya. Intensitas bermain dengan teman sebayanya secara perlahan akan semakin berkurang, sehingga sosialisasi dengan lingkungan sekitar pun semakin berkurang. Pebriana (2017) menunjukkan bahwa salah satu dampak negatif penggunaan gadget adalah keluhan orang tua terhadap ketidakpatuhan anak saat disuruh untuk membantu mengerjakan pekerjaan rumah atau bahkan belajar.berbicara tentang dampak gadget tentu juga akn berbicara efeknya terhadap kesehatan. Menurut Navarona (2016) pada penelitian yang dilakukannya, lama waktu saat menggunakan gadget yang lebih dari dua jam dan pencahayaan yang digunakan saat menggunakan gadget adalah pencahayaan yang terang maka akan berdampak pada gangguan kesehatan mata penggunanya.

Data-data di atas dijadikan awal untuk dilakukannya penelitian pada salah satu kelurahan yang ada di kota Malang, kelurahan Blimbing. Data hasil penelitian yang dilakukan pada tahun 2017 tersebut menunjukkan bahwa mulai terjadi permasalahan terkait interaksi sosial anak terhadap teman sebayanya, kesehatan mata, kepatuhan terhadap perintah orangtua, dan permasalahan yang paling utama adalah kecenderungan adiksi terhadap gadget. Hal ini terlihat dari 18 dari 20 anak sekolah kelas 3 sampai 6 berada dalam kategori tinggi untuk hasil skor kecenderungan adiksi dan 2 lainnya berada dalam kategori rendah. Juga terdapat 19 anak yang menggunakan gadgetnya lebih dari 3 jam dalam sehari menurut Judhita (2011) anak usia sekolah di kelurahan Blimbing masuk dalam kategori pengguna gadget dengan intensitas tinggi. Penggunaan gadget yang dilakukan anak-anak kelurahan Blimbing sebagian besar adalah untuk mengakses sosial media dan juga bermain game yang terhubung dengan jaringan internet seperti mobile legend.

Banyaknya perangkat teknologi dengan mudah diakses dan gadget-gadget yang menggunakan jaringan internet membantu anak usia sekolah untuk memenuhi kebutuhannya dalam mencari hiburan. Banyak permainan-permainan yang terhubung oleh internet (internet gaming) yang menawarkan kelebihan-kelebihan yang bisa membuat anak-anak semakin betah untuk menggunakannya. Sejak tahun 2012 internet gaming merupakan permainan populer yang dimainkan lebih dari satu miliyar orang (Kuss, 2013). Internet gaming yang membebaskan para pemain untuk menciptakan dunia mereka sendiri, seperti menciptakan karakter yang sesuai dengan keinginan mereka, dan juga bebas bermain dengan pemain yang berada di lokasi lain. Hal ini membuat para pemain menjadi lebih sibuk dalam kehidupannya di dalam permainan sehingga membuat kabur antara yang nyata dan yang tidak. Menurut Griffiths dan Pones (2015), para gamer akan mengorbankan waktu dan aktivitas lain untuk bermain game, seperti untuk melakukan hobi-hobi lain, waktu tidur, bekerja ataupun belajar, bersosialisasi dengan teman dan keluarga. Anak-anak dan remaja dianggap lebih rentan terhadap memainkan game online dibandingkan orang dewasa (Griffiths \& Wood, 2000).

Berbagai penelitian terkait internet gaming disorder (IGD) telah dilakukan di berbagai negara dan pada umumnya dilakukan di kalangan remaja. Salah satunya yang dilakukan pada anak muda di Amerika yang berusia 8-18 tahun, 8,5\% dari mereka teridentifikasi berada dalam internet gaming disorder rate (Gentile, 2009). Dalam artikel yang ditulis oleh Markey \& Furguson (2017) hampir 19000 partisipan dari Amerika, Inggris, Kanada, dan Jerman yang sudah mengisi cheklis memiliki simptom-simptom yang bisa 
didiagnosis sebagai simptom internet gaming disorder. Selain itu, penelitian tentang prediksi simptom internet gaming disorder di remaja awal oleh Peeters, Koring, dan Eijnden (2017) yang mengungkapkan adanya efek kerentanan sosial dan kepuasan hidup dalam peningkatan gejala IGD dikalangan usia muda.

Penelitian lain yang dilakukan oleh Wartberg, Kriston, Kramer, Schwedler, Lincoln, \& Kammerl (2016) menjelaskan bahwa terdapat hubungan yang signifikan antara internet gaming disorder dan remaja laki-laki, permasalah kontrol emosi, harga diri, kurangnya perhatian serta kecemasan orangtua. Menurut Sioni, Bulerson, dan Bekerian (2017) dalam penelitiannya mengeksplorasi adanya hubungan yang signifikan antara gejala IGD dengan dua faktor potensi lain yang beresiko yakni fobia sosial dan juga intentifikasi avatar (karakter) yang dikuakan gamer dalam jam mingguan mereka memainkan game internet. Penelitian lain juga dilakukan oleh Bargeron \& Hormes (2016) tentang korelasi psikososial dari internet gaming disorder yang menjelaskan tentang gejala-gejala pada orang-orang dengan IGD termasuk melakukan kebiasaan buruk di sekolah karena waktu bermain mereka yang berlebihan, melewatkan tugas lain, menghabiskan banyak waktu untuk berfikir tentang game mereka, dan penggunaan video game untuk menghindari masalah atau perasaan negatif tertentu.

Beberapa bukti yang dipaparkan di atas kemudian didukung oleh masuknya internet gaming disorder dalam gangguan di DSM-V terbaru karena dampak negatifnya yang dilaporkan sangat luas baikdalam kesehatan mental maupun fisik individu. Dalam DSM$\mathrm{V}$ yang terbaru ini, American Psychiatric Association (APA) menerapkan beberapa perubahan pada deskripsi dan kriteria perilaku-perilaku patologis dan didalamnya termasuk internet gaming disorder sebagai gangguan didalam appendix manual ini (APA, 2013). Pengenalan tentang dampak internet gaming disorder sejak dini Pengenalan tentang identifikasi internet gamig disorder sejak dini pada anak usia sekolah sangat berguna agar bisa dengan cepat megetahui cara penanganan, dan pencegahan yang pas agar tidak bisa mengurangi dampak yang ditimbulkan, serta bisa menjadi referensi dalam penelitian-penelitian lain kedepannya. Hal tersebut meningkatkan urgensi dalam penanganan permasalahan ini terutama jika telah dilakukan semenjak usia anak sekolah. Untuk itu, peneliti mencoba menarik permasalahan internet gaming disorder (IGD) pada anak usia sekolah sebagai sebuah isu yang akan dicegah menggunakan intervensi yang sesuai. Peneliti tertarik untuk mengambil sampel anak usia sekolah karena pada masa ini anak lebih sering rentan terhadap jenis-jenis permainan internet.

Pengangan untuk permasalahan internet gaming disorder telah dilalukan di berbagai penelitian. Seperti penelitian Rodriguez \& Griffith (2017) yang membahas penaganan IGD pada remaja berusia 12-18 tahun. Rodriguez \& Griffith (2017) menggunakan metode PIPATIC yang memakai konsep pelatihan sebagai salah satu item program. Oleh karena itu dalam penelitian ini peneliti akan mengacu pada konsep pelatihan. Peneliti akan menggunakan pelatihan kontrol diri dapat digunakan untuk menangani permasalahan perilaku dan kognisi agar sesuai dengan apa yang diinginkan. Menurut Janah (2014) pelatihan kontrol diri berpengaruh signifikan dalam mengurangi perilaku merokok pada siswa. Rokok termasuk dalam substance dependence begitu pula dengan internet gaming dalam penelitian yang dilakukan oleh Kuss (2013) yang ditemukan memiliki banyak kesamaan dengan adiksi lainnya pada temasuk substance dependence pada level molekular, dan perilakunya. Young (2009) juga menganggap ada kesaam dari 
kriteria substance dependance dalam DSM-IV dengan yang ia temukan pada subjek adiksi internet.

Metode pelatihan dapat dilakukan pada anak usia sekolah mengacu pada penjelasan Santrock (2011) bahwa anak usia sekolah sudah mulai bisa berpikir kritis dan logis, serta mulai mengembangkan strategi pemecahan masalah. Pelatihan yang akan dilakukan berisi identifikasi, edukasi, mini game dan Informational Video akan membatu anak membentuk perspektif dan perilaku anak serta menangani terjadinya IGD sejak dini pada anak usia sekolah. Upaya penanganan tersebut merupakan tujuan sekaligus manfaat dari penelitian ini, yaitu mengidentifikasi apakah pilihan intervensi yang digunakan dapat mengurangi tingkat internet gaming disorder pada anak usia sekolah.

\section{Pelatihan Kontrol Diri dan Internet Gaming Disorer}

Penelitian tentang treatment pada IGD dengan menggunakan metode PIPATIC, yang terdiri dari motivational interviewing, edukasi, person-centered therapy, self regulation training strategies untuk remaja. Dari beberapa alternatif yang telah diberikan, peneliti muncul dengan ide yaitu pelatihan kontrol diri berisi edukasi, identifikasi, games yang akan menyasar pada kognitif dan perilaku anak.

Pelatihan merupakan kegiatan yang dirancang untuk memodifikasi pengetahuan, keterampilan dan sikap melalui proses pengalaman belajar. Edralin (2004) menyebutkan bahwa pelatihan merupakan proses intervensi yang sistematik untuk meningkatkan pengetahuan, kemampuan, dan keterampilan. Sedangkan kontrol diri itu sendiri menurut Chaplin (2006) merupakan suatu upaya yang dilakukan oleh individu untuk membimbing tingkahlakunya agar dapat menekan impuls-impuls dari perilaku impulsif. Kontrol diri lebih pada menekan pada pilihan tindakan dengan cara menunda kepuasaan sesaat (delay gratification). Ghufron dan Risnawita (2010) menyebutkan bahwa kontrol diri merujuk pada kemampuan untuk mengelola faktor dari perilaku yang sesuai dengan kondiri tertentu untuk menampilkan kemampuan mengendalikan perilakunya agar sesuai dan dapat menyenangkan orang lain

Pelatihan kontrol diri yang dilakukan bisa memberikan manfaat dan dampak pada pengaruh yang diinginkan ketika individu tersebut ingin mengontrol dirinya. Pelatihan kontrol diri dapat membantu individu untuk menghadapi suatu kondisi yang terjadi di lingkungan sekitarnya. Para ahli juga berpendapat kontrol diri bisa digunakan sebagai metode intervensi dan juga preventif yang dapat mereduksi efek negatifnya stresor di sekitar. Menurut Averill (Ghufron dan Risnawita, 2010) ada beberapa aspek dalam konrol diri:

1. Behavioral control, yakni kontrol dalam mengambil tindakan

2. Cognitif control, yakni bagaimana memodifikasi proses berfikir seseorang

3. Decission control, yakni kesempatan untuk memilih dan mengambil keputusan atau tujuan alternatif dari tindakan yang akan dilakukan

Kemampuan seseorang dalam mengontrol dirinya menurut Tangney, Baumeister dan Boone (2004) dipengaruhi oleh 3 aspek: a.) melanggar kebiasaan, berkaitan dengan perilaku diluar kebiasaan dan kurang mampu mematuhi norma sekitarnya; b.) menahan 
godaan, berkaitan tentang bagai mana sikap dalam melakukan tugasnya; c.) disiplin diri, berkaitan dengan bagaimana kemampuan untuk mengontrol dirinya.

Averill (dalam Nurhayati, 2013) menyebutkan bahwa ada beberapa aspek-aspek kontrol diri pada individu, diantaranya mengontrol perilaku terdiri dari kemampuan mengatur pelaksanaan dan kemampuan mengontrol stimulus, mengontrol kognitif terdiri dari kemampuan mengolah informasi, kemampuan melakukan penilaian positif serta mengontrol keputusan atau kemampuan mengambil keputusan agar apa yang dilakukan individu mengarah kepada perilaku yang positif. Berdasarkan aspek yang termuat dalam self control dapat diketahui bahwa self control tidak hanya menekankan pada stimulus datangnya perilaku, tetapi juga rasionalis mengenai penilaian perilaku yang akan dimunculkan baik apa tidak. Besarnya efek yang ditimbulkan kontrol diri, beberapa peneliti menyebutkan jika kontrol diri dapat digunakan sebagai metode intervensi (Ghufron dan Rini, 2010).

Kontrol diri tidak dapat berkembang begitu saja, namun kontrol diri dapat dikembangkan melalui latihan yang dilakukan secara terus menerus. Pelatihan kontrol diri sangat bermanfaat untuk dapat mengembangkan kontrol diri itu sendiri dan memberikan dampak positif dalam pengelolaan emosi dan mengurangi perilaku yang buruk bagi individu (Muraven, 2010). Pelatihan sendiri merupakan salah satu cara pengembangan sumber daya manusia. Pengembangan dilakukan meliputi pemberian kesempatan belajar yang bertujuan untuk mengembangkan individu pada saat ini dan masa yang akan mendatang. Pelatihan dilakukan untuk memberikan kegiatan yang berfungsi meningkatkan kinerja seseorang dalam pekerjaan atau tugasnya sekarang. Pelatihan dilakukan untuk membantu individu agar menjadi lebih efektif (Afiatin, 2013).

Seperti yang sudah dijelaskan, subjek dengan IGD sering menunjukkan gangguan pada kognitif yang berkaitan dengan perilaku impulsif yang meningkat, serta gangguan kontrol kognitif dan juga waktu. Subjek IGD juga menunjukkan beberapa perasaan negatif seperti rasa cemas dan tidak bisa lepas dari bermain game. Dengan melatih kontrol diri yang bisa membantu menekan perasaan negatif dan stimulus yang mendorong munculnya perilaku negatif. Seperti metode PIPATIC yang mana salah satu metode yang digunakan adalah metode strategi pelatihan, peneliti juga akan menggunakan metode pelatihan yakni pelatihan kontrol diri yang akan diberikan pada anak usia sekolah. Menurut Piaget (Santrock, 2011) pada usia sekitar 6 hingga 12 tahun anak berada pada tahap operational konkret, pada tahap ini anak-anak dapat melakukan operasi konkret, mereka juga dapat bernalar secara logis sejauh penalaran itu dapat diaplikasikan pada contoh-contoh yang spesifik atau konkret. Dari penjelasan tersebut metode pelatihan kontrol diri dapat diaplikasikan dengan baik. Dengan memberikan bukan hanya edukasi tetapi juga identifikasi, video informatif serta mini game yang akan sedikit banyak memobilisasi efek perubahan kognitif dan perilaku anak, juga akan berpengaruh besar dalam pembentukan perpektif pada anak.

\section{Hipotesis}

Pelatihan kontrol diri dapat mengurangi internet gaming disorder anak usia 9-11 tahun di SD. 


\section{METODE}

Pada penelitian ini, pendekatan yang digunakan adalah kuantitatif dan berjenis eksperimen penelitian eksperimen dilakukan untuk mengetahui akibat yang ditimbulakn dari suatu perlakuan yang diberikan. Latipun (2002) menjelaskan bahwa eksperimen dilakukan dengan mengadakan manipulasi perlakuan yang bertujuan untuk mengetahui akibat manipulasi terhadap perilaku individu yang diamati. Desain eksperimen yang digunakan dalam penelitian ini adalah desain between subject dan model pretest-posttest kontrol group design. Dalam desain ini terdapat dua kelompok (eksperimen dan kontrol) yang dipilih kemudian menilai perbedaan diantara dua kelompok.

\section{Tabel 1 skema desain eksperimen}

\begin{tabular}{cccc}
\hline Kelompok & Tahap I & Tahap II & Tahap III \\
\hline Eksperimen & Pretest & Perlakuan & Post-test \\
\hline Kontrol & Pretest & - & Post-test \\
\hline
\end{tabular}

Subjek penelitian ini adalah siswa sekolah dasar. Pengambilan subjek menggunakan teknik purposive sampling yaitu teknik pengambilan sampel berdasarkan pertimbangan tertentu (Sugiyono, 2014). Subjek yang digunakan berjumlah 12 orang dimana 6 subjek masuk pada kelompok eksperimen dan 6 orang subjek pada kelompok kontrol. Kriteria dalam penentuan subjek adalah anak usia 9-111 tahun, bersekolah di SDN Mojolangu 5, orangtua bersedia menjadi subjek penelitian dan anak memiliki skor tinggi skor skala IGD20-test yang tinggi. Pembagian subjek kedalam kelompok kontrol dan kelompok eksperimen dilakukan dengan melihat urutan skor pretest subjek. Bagi subjek yang memiliki skor pretest tinggi 6 pertama akan dimasukkan kedalam kelompok eksperimen dan 6 subjek lainnya ditempatkan pada kelompok kontrol.

Peneliatian eksperimen meneliti hubungan sebab akibat dan bukan hanya meneliti hubungan antar variabel. Dalam penelitina ini akan meneliti 2 variabel, variabel bebas bebas atau $\mathrm{X}$ adalah Pelatihan kontrol diri dan untuk variabel terikat atau $\mathrm{Y}$ adalah Internet Gaming Disorder

Pelatihan kontrol diri adalah suatu metode intervensi yang dilakukan untuk memberikan keterampilan pada indivisu agar bisa mengendalikan dorongan-dorongan yang ada dalam dirinya serta sekitarnya. Pelatihan yang akan dilakukan dengan pemberian edukasi dan video-video informatif terkait internet gaming, faktor-faktor penghambat dan pendorong, dampak negatif bila berlebihan games, tips bagaimana megurangi, mini game, serta pemberian remind card sebagai tugas untuk mengurangi penggunaan internet gaming. Setiap kegiatan pada pelatihan ini memiliki makna yang tersembunyi, dan manfaat dari kegiatan-kegiatan tersebut adalah memberikan pengetahuan, keterampilan, dan sikap mengontrol diri sendiri. 
Tabel 2 Kegiatan Pelatihan dan Aspek Kontrol Diri

\begin{tabular}{|c|c|}
\hline Kegiatan & Bentuk Kegiatan \\
\hline $\begin{array}{l}\text { Butter cake } \\
\text { jelly }\end{array}$ & $\begin{array}{l}\text { Anak akan diberi berbagai } \\
\text { macam warna bola dimana tiap } \\
\text { warna bola memiliki instruksi } \\
\text { yang berbeda-beda }\end{array}$ \\
\hline $\begin{array}{l}\text { Pemberian } \\
\text { materi dna } \\
\text { juga } \\
\text { pemberian } \\
\text { video } \\
\text { informatif }\end{array}$ & $\begin{array}{l}\text { Kegiatan ini akan memberikan } \\
\text { gambaran kepada anak tentang } \\
\text { permasalahan dalam bermain } \\
\text { game yang sedang dihadapnya, } \\
\text { apa saja faktor penyebab dan } \\
\text { pendorong, Kegiatan ini juga } \\
\text { akan disuguhkan dengan video } \\
\text { informatif }\end{array}$ \\
\hline $\begin{array}{l}\text { Lembar } \\
\text { evaluasi }\end{array}$ & $\begin{array}{l}\text { Anak diminta untuk menjawab } \\
\text { pertaanyaan yang ada serta } \\
\text { membeyankan konsekuensi yang } \\
\text { kan didapat jika melakukan apa } \\
\text { yang tertulus pada kertas } \\
\text { tersebut. }\end{array}$ \\
\hline
\end{tabular}

Aspek Kontrol Diri

Kegiatan ini mencerminkan

bagaimana anak akan

mengolah stimulus yang

diterima dengan peraturan

yang ada, serta keputusan

apa yang akan dilakukan

saat menerima stimulus

tersebut.

Aspek kontrol perilaku, kontrol kognisi, dan kontrol keputusan.

Kegiatan ini mencerminkan bagaimana anak akan mengambil keputusan terkait menahan dorongan negative atau membiarkannya. Hal tersebut termasuk kedalam aspek kontrol keputusan dalam kontrol diri.

Engklek Anak akan melakukan Melatih anak agar mampu menara permainan engklek secara bergantian sesuai urutan bernain.. mengambil keputusan, melatih kesabaran, dan pengendalian diri, mengontrol emosi dengan harus bisamengendalikan responnya agar gaju tidak jatuh dan lompatan tidak terkena garis pembatas. Anak juga belajar untuk menunggu bergiliran untuk main yang bisa melatih penundaan kepuasan.

Ketek karet Anak akan bergantian bermain Anak akan mengolah dengan sejumlah karet yang informasi atau stimulus 
dimiliki untuk menjatuhkan tumpukan-tumpukan karet yang ada didepannya.

\section{Remind card}

yang diterima dengan
peraturan yang ada.
Bagaimana anak dapat
melakukan hal tersebut
terkait dengan aspek
kognitif dalam kontrol diri.
Anak juga belajar untuk
mengambil keputusan dan
juga melatih kesabaran
dalam mengontrol
emosinya.

Kontrol Perilaku, Kontrol Kognitif, dan Kontrol Keputusan.

Dalam kegiatan ini anak akan belajar bagaimana ia mengontrol stimulus yang tersedia dan mengalihan dengan melakukan kegiatan positif lainnya, anak juga belajar mengontrol keputusan akan mengikuti sesuai tugas yang diberikan atau mebiarkannya.

Internet gaming disorder adalah salah satu bentuk gangguan terkait adiksi internet yang digunakan untuk bermain memainkan permainan yang terhubung oleh internet, berkaitan dengan berbagai dampak negatif dari game yang dimainkannya. Ciri utama dari internet gaming disorder yaitu menetap dan dilakukan berulang atau menerus.Faktor penyebab bisa digunakan sebagai media penarikan diri, dan juga bentuk dari coping.

Data penelitian diperoleh melalui instrumen model pengukuran skala. Arikunto (2002) menjelaskan bahwa instrumen penelitian adalah alat yang digunakan oleh peneliti dalam mengumpulkan data agar memudahkan pengerjaan dalam penelitian dan hasilnya lebih baik (dalam artian lebih cermat, sisematis, dan lengkap) sehingga menjadi lebih mudah untuk diolah. Instrumen yang digunakan dalam penelitian ini adalah adaptasi dari skala IGD20-test, yang digunakan sebelum (pretest) dan sesudah (post-test) diberikannya intervensi atau perlakuan. Skala ini didasarkan dari 9 kriteria atau simptom disorder dari DSM-V dan menggabungkan kerangka teoritis dari komponen adiksi (salience, mood modification, tolerance, withdrawal symptoms, conflict dan relapse). IGD 20-Test yang memiliki jumlah item 14 dengan indeks validitas 0,345-0,590 serta angka reliabilitas sebesar 0,83 .

Pada tahap persiapan atau pra-intervensi, peneliti melakukan pendalaman materi seperti pembuatan modul dan juga adaptasi alat ukur IGD 20-Test dan selanjutnya akan dilakukan simulasi. Proses adaptasi skala terlebih dahulu dilakukan dengan prosedur 
pengadaptasian yakni menterjemahkan bahasa ke bahsa indonesia, kemudian diterjemahkan lagi kebahasa asal skala hingga diperoleh kesamaan makna. Asesmen awal dilakukan peneliti dengan mewawancarai anak terkait penggunaan game internet Selanjutnya peneliti menyebar skala untuk memperoleh hasil pretest. Ketika hasil pretest telah diketahui, akan diseleksi subjek dengan melihat skor yang diperoleh berdasarkan norma kelompok, kemudian mengikuti kegiatan intervensi. Berikut adalah norma yang disajikan dalam tabel.

Tabel 3 kategori skala IGD-20 test

\begin{tabular}{cc}
\hline Skor & Kategori \\
\hline $14-28$ & Rendah \\
$29-40$ & Sedang \\
$41-70$ & Tinggi \\
\hline
\end{tabular}

Tahap Intervensi, peneliti memberikan perlakuan pada 6 anak kelompok eksperimen yaitu perlakuan berupa pelatihan yang dibagi menjadi dua sesi. Pada sesi pertama intervensionis/peneliti akan memberikan edukasi atau membantu identifikasi problem situasi yang dihadapi, emosi, serta bagaimana pikiran anak terhadap permasalah yang sedang dihadapi, mengidentifikasi/membagikan pengalam pribadi tentang apa saja faktor pendorong dan penghambat, serta ulasan tentang materi yang telah diberikan dengan memberikan waktu untuk tanya jawab dan mengerjakan lembar enaluasi kepada anak. Pada sesi kedua akan mengulas kembali materi sebelumnya secara singkat, meberikan materi dengan media video-video yang ditampilkan (akibat atau dampak dari penggunaan yang berlebih, bagaimana cara mengurangi dan mengatasi), setelah itu merangkum dengan memberikan list cara-cara yang sudah dipelajari, dan juga games. Pada akhir sesi kedua ini anak akan diberikan remind card yang berisi tugas-tugas yang dilakukan anak setelah diberi perlakuan. Setelah seminggu berlalu setelah sesi kedua peneliti akan mengambil kembali dan mengadministrasikan kembali alat ukur atau skala untuk dilakukannya post-test.

Tahap pasca-intervensi atau anlisa data, pada tahap ini peneliti menganalisa hasil dari data pretest dan post-test yang diperoleh. Data yang diperoleh diinput dan diolah menggunakan analisa Mann Whitney untuk masing-masing kelompok. Kemudian membandingkan perbedaan hasil skor pretest dan post-test dengan analisis Wilcoxon Signed Ranks Test. Peneliti juga mengikutsertakan data penunjang seperti hasil observasi dan hasil dari remind card. Setelah itu peneliti mengambil kesimpulan dari penelitian yang telah dilakukan.

\section{HASIL}

Setelah penelitian dilakukan, diperoleh beberapa hasil yang akan dipaparkan dengan tabel-tabel dan gambar bagan berikut. Tabel pertama merupakan deskripsi dari karakteristik subjek dalam pelatihan kontrol diri untuk mengurangi internet gaming disorder berdasarkan hasil sampling dengan metode purposive sampling. Subjek pada 
penelitian ini terbagi menjadi dua kelompok yaitu kelompok eksperimen dan kelompok kontrol.

Tabel 4 Deskripsi karakteristik Subjek

\begin{tabular}{llll}
\hline & Kategori & Kelompok Eksperimen & Kelompok Kontrol \\
\hline \multirow{2}{*}{ Usia } & Anak-anak & $10-11$ & $9-11$ \\
& Akhir & & 5 orang \\
\multirow{2}{*}{ Jenis Kelamin } & Laki-laki & 4 orang & 1 orang \\
Rata-rata Skor & Perempuan & 2 orang & 44,67 \\
\hline
\end{tabular}

Berdasarkan tabel 2 di atas subjek yang menjadi peserta pelatihan adalah siswa yang termasuk dalam rentang anak-anak akhir. Pada kelompok eksperimen terdiri dari 6 anak yaitu 4 anak laki-laki dan 2 anak perempuan dengan rentang usia 10-11 tahun, sedangkan untuk kelompok kontrol terdiri dari 6 anak yaitu 5 laki-laki dan 1 perempuan dengan rentang usia 9-11 tahun.

Peneliti menganalisis skor pretest pada kedua kelompok tersebut dengan menggunakan uji Mann whitney untuk melihat kesetaraan kelompok sebelum diberikan perlakuan berupa pelattihan kontrol diri.

Tabel 5 Deskriptif Uji Mann-Whitney pada Data Pretest Kelompok Eksperimen dan Kelompok Kontrol

\begin{tabular}{lcccc}
\hline Kelompok & N & Mean Rank & Z & Asymp. Sig. \\
\hline Eksperimen & 6 & 6,17 &,- 328 & \multirow{2}{*}{743} \\
Kontrol & 6 & 6,83 & & \\
\hline
\end{tabular}

Dari tabel 4 dapat diperoleh nilai Sig sebesar 0,74>0,05 yang menunjukkan tidak ada perbedaan sebelum diberi perlakuan. Hal tersebut menunjukan bahwa data awal pada kedua kelompok sama. Dengan demikian dapat disimpulkan bahwa kondisi kedua kelompok setara sebelum diberikan perlakuan pelatihan kontrol diri.

Selanjutnya peneliti melakukan uji analisis Mann Whitney untuk mengetahui apakah ada perbedaan dari kedua kelompok setelah diberikan perlakuan pelatihan kontrol diri.

Tabel 6 Deskripsi Uji Mann-Whitney pada Data Posttest Kelompok Eksperimen dan Kelompok Kontrol

\begin{tabular}{lcccc}
\hline Kelompok & N & Mean Rank & Z & Asymp. Sig. \\
\hline Eksperimen & 6 & 4,25 & $-2,189$ &, 029 \\
Kontrol & 6 & 8,75 & & \\
\hline
\end{tabular}

Berdasarkan hasil uji pada tabel 5 diperoleh hasil nilai $\mathrm{z}=-2,189$ dan nilai Sig $=0,029$ Sig < 0,05. Hal ini menandakan bahwa terdapat perbedaan yang signifikan pada kelompok eksperimen dan kelompok kontrol setelah diberikan perlakuan pelatihan kontrol diri. Tabel di atas juga menujukkan bahwa rata-rata skor dari kelompok 
ekperimen sebesar 4.25 lebih rendah dibandingkan dengan skor dari kelompok kontrol yang sebesar 8.75. Hal tersebut juga menunjukkan bahwa rata-rata skor pada kelompok eksperimen yang telah diberi perlakuan pelatihan kontrol diri lebih rendah jika dibandingkan dengan rata-rata skor kelompok kontrol yang tidak diberikan perlakuan.

Langkah terakhir untuk hasil penelitian, peneliti melakukan uji analisis Wilcoxon untuk mengetahui gambaran tingkat pada kedua kelompok di dua kondisi yang berbeda yaitu pretest dan posttest.

Tabel 7 Deskripsi Uji Wilcoxon pada Data Pretest dan Posttest Kelompok Eksperimen dan Kelompok Kontrol

\begin{tabular}{lccccc}
\hline \multirow{2}{*}{ Kelompok } & N & \multicolumn{2}{c}{ Rata-rata Skor } & & Asymp. \\
\cline { 3 - 4 } & & Pretest & Posttest & & Sig. \\
\hline Eksperimen & 6 & 44,00 & 38,33 & $-2,032$ & 0.042 \\
Kontrol & 6 & 44,67 & 44 &,- 378 & 0.705 \\
\hline
\end{tabular}

Berdasarkan hasil uji analisis Wilcoxon pada Tabel 6 pada kelompok eksperimen diperoleh hasil nilai Sig. $=0.042$, Sig. $<0.05$. Hasil tersebut menunjukkan adanya perbedaan yang signifikan pada skor pretest dan posttest kelompok eksperimen. Hasil tersebut juga menunjukkan bahwa perlakuan berupa pelatihan kontrol diri dapat memberikan efek pengaruh untuk mengurangi internet gaming disorder pada kelompok eksperimen yang telah diberi perlakuan. Sementara itu, berdasarkan hasil uji analisis Wilcoxon pada tabel 6 pada kelompok kontrol diperoleh nilai Sig. $=0.705$, Sig. $>0.05$. Hasil tersebut menunjukkan bahwa tidak terdapat perbedaan yang signifikan pada skor pretest dan posttest kelompok kontrol.

Dari hasil analisa kuantitatif yang dilakukan dapat disimpulkan bahwa perlakuan berupa pelatihan kontrol diri dapat digunakan sebagai media untuk mengurangi kecenderungan internet gaming disorder pada anak. Hasil penelitian juga menunjukkan bahwa skor pada kelompok eksperimen lebih rendah dibandingkan kelompok kontrol setelah diberikan perlakuan.

Hasil analisis data kuantitatif di atas didukung dengan hasil dari data remind card yang telah dikumpulkan pada kelompok eksperimen. Remind card ini digunakan untuk mengontrol berapa lama waktu durasi bermain game dan juga mengetahui jenis-jenis aktivitas fisik lain apa saja yang bisa mengalihkan kelompok eksperimen selain bermain game internet dalam setiap harinya selama satu minggu. Berikut hasil dari remind card. 


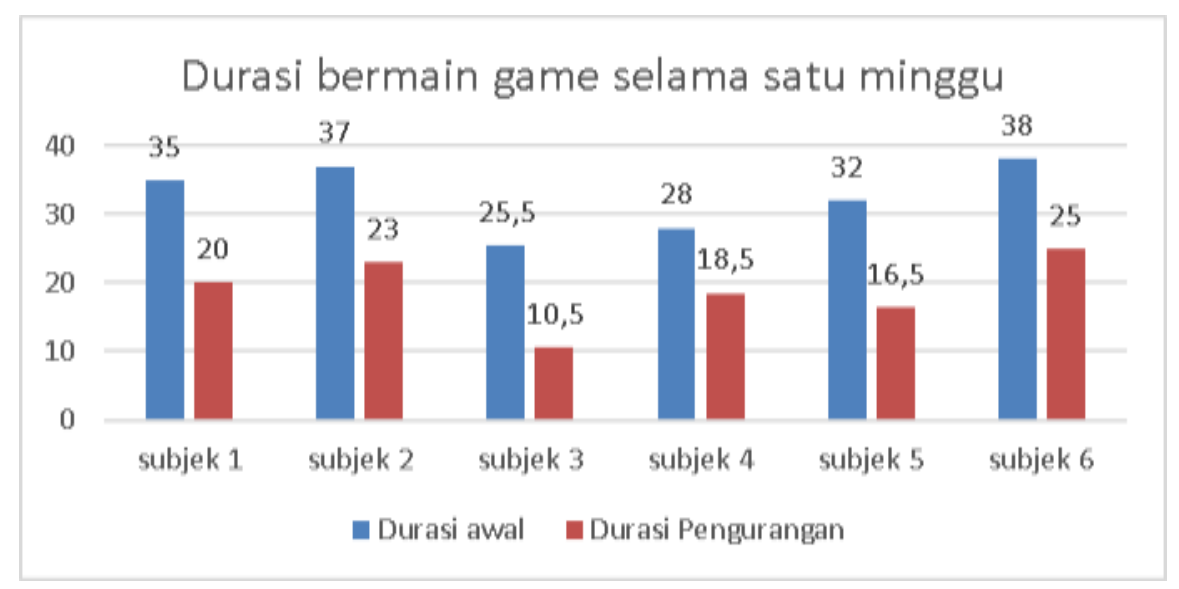

Gambar 1 Total durasi bermain game per jam dalam satu minggu

Dari gambar 1 menunjukkan hasil remind card selama satu minggu setelah diberikan pelatihan kontrol diri. ada gambar 1 terlihat adanya penurunan durasi bermain game dalam kurun waktu satu minggu pada anak kelompok eksperimen setelah diberikan perlakuan pelatihan kontrol diri. Hal ini menunjukkan bahwa setelah pelatihan kontrol diri anak mulai bisa mengontroldurasi dalam bermain game internet. Selanjutnya adalah gambaran aktivitas lain selain bermain game internet pada anak-anak kelompok eksperimen setelah diberikan perlakuan pelatihan kontrol diri.

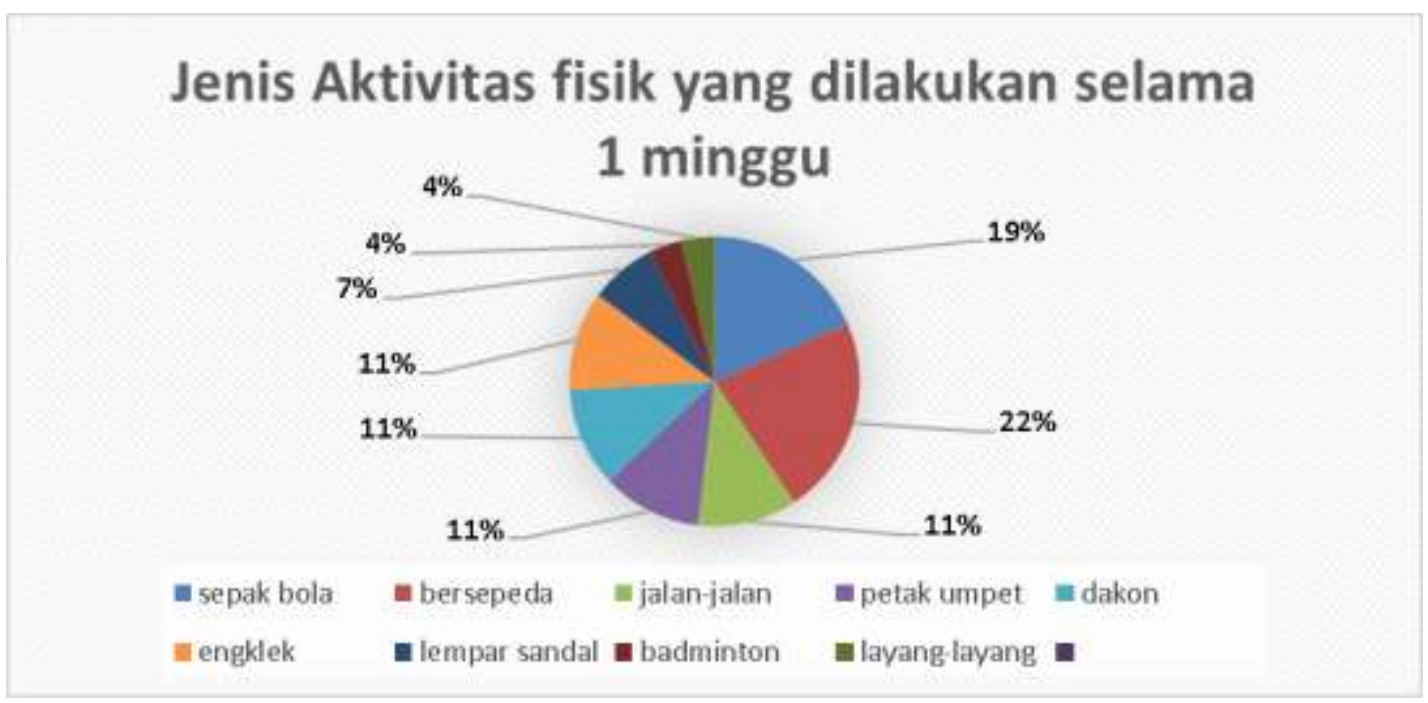

Gambar 2 Jenis aktivitas fisik yang dilakukan selama 1 minggu

Dari gambar 2 menunjukkan hasil remind card selama 1 minggu setelah diberikannya perlakuan pelatihan kontrol diri pada kelompok eksperimen. Dari gambar dapat dilihat bahwa sebagian besar anak melakukan kegiatan aktivitas fisik lain berupa bersepeda (22\%) untuk mengalihkan dari bermain game internet. Lalu selanjutnya ada sepak bola $(19 \%)$, bermain petak umpet (11\%), bermain engklek (11\%), bermain dakon (11\%), serta jalan-jalan (11\%). Hal ini dapat membiasakan anak melakukan aktivitas yang dapat mereka menguragi bermain game internet sehar-hari, terlebih melakukan aktivitas yang menyenangkan bagi anak-anak memfasilitasi dan mendorong anak untuk melakukan 
aktivitas diluar akan sedikit membantuuntuk tidak bergantung pada internet dan juga sebagai untuk mengontrol diri agar mengurangi dampak dari internet gaming disorder.

\section{DISKUSI}

Pemaparan hasil analisa data yang telah dilakukan menunjukkan bahwa adanya pengaruh yang signifikan dari pelatihan kontrol diri yang dilakukan terhadap tingkat internet gaming disorder pada anak SDN Mojolangu 5. Pelatihan kontrol diri yang merupakan suatu metode intervensi untuk memberikan keterampilan pada individu agar bisa mengendalikan dorongan-dorongan yang ada dalam dirinya serta sekitarnya cukup efektif untuk mengurangi tingkat internet gaming disorder pada anak usia sekolah. Hal ini dibuktikan berdasarkan uji analisa data yang telah dilakukan menujukkan bahwa adanya perbedaan tingkat internet gaming disorder pada kelompok eksperimen dengan kelompok kontrol sebelum diberikan perlakuan (pretest) dengan setelah diberikan peelakuan (posttest). Kelompok eksperimen mengalami penurunan tingkat internet gaming disorder yang signifikan setelah diberikanya perlakuan berupa pelatihan kontrol diri dibandingkan dengan kelompok kontrol.

Internet gaming disorder merupakan sejenis perilaku adiksi yang didefinisikan sebagai perilaku kehilangan kontrol atau kendali, dan penggunaan game internet secara terusmenerus dan berulang yang memiliki ciri utama yakni penggunaan yang menetap untuk waktu yang lama.. Wartberg et al. (2016) menjelaskan bahwa terdapat hubungan yang signifikan antara internet gaming disorder dan remaja laki-laki, permasalah kontrol emosi. Penelitian yang dilakukan oleh Rho, Hyeseon, Taek-ho, Hyun, Dongjin, Dai-jin, \& In Young (2017) juga menunjukkan bahwa laki-laki lebih rentan untuk masuk dalam grup internet gaming diorder dibandingkan dengan perempuan. Hal ini seperti penelitian yang dilakukan bahwa subjek yang memeuhi kriteria dalam penelitian ini lebih banyak berjenis kelamin laki-laki dibandingkan dengan perempuan.

IGD sering menunjukkan gangguan pada kognitif yang berkaitan dengan perilaku impulsif yang meningkat, serta gangguan kontrol kognitif dan juga waktu.Secara khusus impulsifitas dan pengendalian diri merupakan faktor psikologis yang penting yang mempengaruhi kecanduan. Impulsifitas telah dilaporkan sebagai resiko untuk kecanduan seperti smartphone ataupun mengakses internet (Wu, Cheung, $\mathrm{Ku}$, Hung, 2013) dan juga kontrol diri sering dikaitkan dengan kecanduan seperti substance use dan juga penggunaan internet (Park, Park, Shin, Li, Rolfe, Yoo, \& Dittmore, 2016). Dalam penelitian ini perlakuan yang dipilih untuk mengurangi internet gaming disorder adalah penggunakan pelatihan kontrol diri.

Pelatihan berkaitan dengan proses pembelajaran pada individu agar mendapatkan pengetahuan, ketarampilan, dan sikap yang dibutuhkan. Pelatihan yang diberikan dalam penelitian ini berfungsi untuk mengembangkan potensi yang ada dalam diri khususnya kontrol diri. Kontrol diri dapat dikembangkan melalui latihan sederhana dengan memfokuskan pada kegiatan yang secara langsung mempraktikkan pengontrolan diri dan mengerahkan kontrol diri serta kekuatan pengendalian (Muraven, 2010). Seperti halnya dengan pelatihan kontrol diri dalam penelitian ini, kegiatan yang terdapat dalam 
pelatihan ini menekankan pada pembelajaran langsung mengenai pengembangan kontrol diri melalui materi yang diberikan dan permainan-permainan yang dilakukan.

Kontrol diri merupakan salah satu bagian terpenting yang terdapat dalam diri manusia karena memungkinkan individu untuk membatasi perilaku impulsif. Kontrol diri yang buruk akan menyebabkan individu melakukan banyak perilaku negatif seperti kriminalitas, perilaku seksual beresiko, penggunaan narkoba dan alkohol. Sebaliknya, pengendalian diri yang tinggi memberikan dampak yang positif seperti mengurangi psikopatologi, hubungan yang lebih baik, keterampilan interpersonal yang lebih baik, kontrol emosional yang lebih baik, serta dampak positif lainnya (Rho, Lee, \& Lee 2017). Dengan kata lain jika anak memiliki kontrol diri yang baik maka anak akan bisa mengontrol diri mereka agar bisa mengurangi dampak negatif dari penggunaan internet gaming yang berlebih.

Pelatihan menurut Michael (dalam Moejikat, 1991) menunjukkan setiap proses untuk mengembangkan bakat, keterampilan, dan kemampuan guna menyelesaikan pekerjaan tertentu dengan fokus kegiatannya adalah meningkatkan kemampuan untuk memenuhi kebutuhan pada masa sekarang. Pelatihan merupakan proses pembelajaran dalam meningkatkan pengetahuan, sikap, dan keterampilan. Keterampilan seseorang untuk mengatur dirinya sendiri mencakup kesadaran diri dan keterampilan diri salah satunya adalah kontrol diri. Seperti pelatihan kontrol diri yang dilakukan untuk membantu anak dalam melatih keterampila mengatur dirinya sendiri agar dapat mengurangi dampak penggunaan internet gaming.

Metode intervensi yang dilakukan dalam mengurangi internet gaming disorder ini menggunakan pelathan kontrol diri, yang didalamnya terdapat pemberian materi mengenai iinternet gaming dengan memberikan informasi materi salah satunya menggunakan media video yang akan membantu anak lebih mudah menyerap informasi yang didapatkan. Seperti yang dilakukan Shah, Mathur, Kathuria \& Gupta (2016) penelitian tersebut menyasar pada anak-anak yang menunggu di ruang tunggu dokter gigi. Pemberian video edukasi bertujuan untuk memberikan pengetahuan yang lebih baik tentang kesehatan mulut pada anak-anak tersebut. Hasil penelitiannya menunjukkan perbedaan yang signifikan antara subjek yang dipertontonkan video tersebut dengan yang tidak dipertontonkan. Hal tersebut menunjukkan bahwa pemberian informasi melalui video cukup efektif dalam menyasar kognitif anak.

Dalam pelatihan kontrol diri yang dilakukan juga menggunakan metode pembelajaran melalui bermain, permainan-permainan yang digunakan seperti engklek, ketek karet, estafet kelereng, dan juga mini games lain. Metode intervensi melalui metode pembelajaran menggunakan permainan pada anak Di masa kanak-kanak ini bermain sangatlah berperan penting dalam hal pembelajaran dan juga perkembangan, dengan bermain anak dapat mengeksplor dirinya mengenai lingkungan, bersosiallisasi dengan teman sebayanya dan juga memiliki banyak pengalaman (Khasanah, Prasetyo \& Rakhmawati, 2011).

Piaget dalam teorinya, mengklasifikasikan anak usia sekolah dasar ke dalam tahapan pola bermain social play games with rules $( \pm$ 8-11 tahun). Dalam buku yang ditulis oleh Iswinarti (2017) anak pada usia sekolah dasar akan memperoleh nilai kompetensi sosial 
dari permainan yang dimainkan. Anak mulai pandai berinteraksi sosial dan bermain dengan teman sebayanya serta mentaati aturan permainan, dan yang paling bagus adalah ketika anak bisa memainkan permainan dengan teman-temannya dengan menggunakan aturan yang dibuat sendiri, dan anak berusaha untuk mematuhinya, dan ketika ada kesalahan mereka bisa menerima sanksi yang diberikan. Dalam penelitian ini anak akan belajar lebih cara mengendalikan dirinya lewat permainan yang diberikan saat pelatihan terlihat dari cara anak yang mengikuti aturan permainan, menunggu giliran bermain, dan anak mengendalikan emosinya seperti mengumpat, marah, menyalahkan teman, jengkel kepada teman, dan sebagainya. Anak juga akan belajar bagaimana cara mengambil keputusan dan problem solving.

Penggunaan remind card di akhir intervensi eksperiman juga merupakan tambahan yang cocok untuk mengidentifikasi sejauh mana anak mengontrol dirinya dalam sehari-hari agar tidak bermain game internet dengan mengalihannnya melakukan kegiatan fisik atau kegiatan lain. Remind card juga sekaligus berfungsi sebagai reinforcement untuk anak melakukan hal lain selain bermain game internet. Konsep ini sudah digunakan pada mini riset yang dilakukan peneliti dan kawan-kawan tentang adiksi gadget pada anak-anak di Kelurahan Blimbing pada akhir tahun 2017. Hasil pengisian dapat membuktikan bahwa kegiatan fisik dapat dilakukan saat anak diberikan tugas untuk tidak bermain game internet. Pemberian rentang waktu dalam satu minggu juga dapat mebiasakan anak untuk memiliki aktivitas lain selain hanya bermain internet.

Menurut Piaget (Ormord, 2010) anak-anak dapat mengonstruksi keyakinan dan pemahaman-pemahaman mereka berdasarkan pengalaman yang telah diperolehnya. Menurut Anderson \& Krathwohl (Suwarto, 2010) terdapat beberapa kategori proses dalam belajar. Kategori pertama yaitu mengingat (remembering) merupakan proses yang sangat berhubungan denagn proses daya ingat tentang materi yang diberikan. Pada proses remembering ini terdapat dua proses kognitif yang berkaitan yaitu anak akan menyadari dan mengingat kembali. Setelah itu anak akan memahami (understanding), seorang anak dapat memahami jika ia dapat menarik suatu pesan dari materi yang telah disampaikan. Proses selanjutnya yaitu penerapan (applying), pada tahap ini anak akan menerapkan apa yang mereka peroleh kedalam perilaku. Pada penelitian ini anak menerapkan apa yang mereka peroleh dari pelatihan kontrol diri kedalam permainan yang ada dalam pelatihan serta dalam tugas-tugas dalam remind card yang telah diberikan.

Yusuf (2006) menyatakan bahwa kognitif manusia terdiri dari tiga bagian yaitu: (1) input, yaitu merupakan stimulus yang didapatkan dari lingkungan yang nantinya akan memasuk ke panca indra manusia (penglihatan, suara dan rasa); (2) Proses, dimana dalam hal ini pengolahan informasi yang dilakukan oleh otak dengan cara yang beragam, dengan tahapan meliputi pengolahan atau penyusunan informasi ke dalam bentuk-bentuk simbolik, membandingkan sesuatu dengan informasi sebelumnya, memasukan ke dalam memorinya dan menggunakannya apabila diperlukan; (3) Output, yaitu hasil yang diperoleh dari tahapan yang berbentuk tingkah laku. Dalam penelitian ini anak menangkap informasi melalui pemberian materi serta anak memahami materi yang diberikan kemudian melakukannya dalam bentuk perilaku yang dimunculkan dalam tugas remind card yakni pengurangan jumlah penggunaan game internet dengan melakukan bermain permainan atau aktivitas fisik lain. 
Graham (Simatupang, 2005) berpendapat bahwa bermain merupakan tingkah laku dari motivasi intrinsik yang dipilih secara bebas, anak melakukan kegiatan karena memang keinginan pribadi, bukan karena orang lain. Raharjo (2007) menyebutkan selain motivasi intrinsik, salah satu karakteristik bermain yakni fleksibel. Anak akan bebas beralih dari aktivitas satu ke aktivitas yang lain dengan mudah dan fleksibel. Dalam penelitian ini terlihat dari remind card yang telah terisi pada tugas pertama terdapat perbedaan tiap anak dalam kelompok eksperimen dalam pengurangan waktu bermain game internet selama satu minggu. Pengurangan waktu bermain game internet tersebut dipengaruhi oleh motivasi intrinsik tiap anak yang berbeda. Hal ini juga berkaitan dengan tugas kedua dalam remind card yakni menuliskan alasan pengurangan waktu bermain game internet dengan melakukan aktifitas sisik lainnya dengan jawaban yang variatif pada tiap anak. Anak-anak pada kelompok eksperimen dengan fleksibel beralih dari bermain game internet menjadi permainan atau aktifitas fisik lainnya.

Ketika anak diberikan media pembelajaran yang menarik untuk dilakukan, anak akan antusias untuk melakukannya secara berulang-ulang Pada masa kanak-kanak, anak banyak berinteraksi dengan teman sebaya melalui kegiatan bermain (Santrock, 2011). Pada penelitian ini, anak diberikan tugas pada akhir pelatihan kontrol diri dalam bentuk menuliskan aktivitas fisik lain bisa berupa permainan yang dapat dimainkan dengan teman sebayanya sehingga anak akan mampu mengurangi penggunaan game internet yang berlebihan. Hasil penelitlian menunjukkan bahwa adanya perubahan hasil internet gaming disorder pada kelompok eksperimen Berdasarkan uji analasis yang dilakukan, terdapat perbedaan yang signifikan pada kedua kelompok setelah diberi perlakuan yaitu $\mathrm{p}=0.042$, dimana nilai $\mathrm{p}<0.05$. hasil tersebut membuktikan bahwa pelatihan kontrol diri ini merupakan suatu perlakuan yang mampu digunakan untuk mengurangi internet gaming disorder pada anak usia 9-11 tahun.

Dengan berbagai kelebihan dan keberhasilan perlakuan yang dilaksanakan, bukan berarti penelitian ini tidak luput dari kekurangan. Masih ada kekurangan dan kelemahan yang perli digarisbawahi agar penelitian kedepannya mendapatkan hasil yang lebih baik. Kekurangan tersebut dimulai dari pemilihan subjek pada tahapan pra-eksperimen atau persiapan sebelum dilakukannya perlakuan. Ada baiknya jika dilakukan secara acak atau random assigment yang sesuai dengan prosedur dalam proses menentukan mana subjek yang masuk dalam kelompok eksperimen dan kontrol. hal tersebut bisa dilakukan dengan pengocokan undian karena konsep dari random assigment adalah seluruh subjek yang memenuhi kriteria berhak berada dalam kelompok eksperimen maupun kelompok kontrol. Juga dalam pengisian remind card sebagai monitoring yang menurut peneliti belum terlaksana dengan baik karena selain pengisian yang tidak dibarengi oleh orangtua, terdapat beberapa anak yang memiliki jadwal kegiatan yang padat yaitu selain sekolah anak juga mengikuti bimbel sehingga beberapa anak yang mengisi tugas tentang aktivitas fisik lain yang dilakukan dalam seminggu hanya seadanya saja.

\section{SIMPULAN DAN IMPLIKASI}

Penelitian ini mencoba mengetahui pengaruh dari pemberian eksperimen pelatihan kontrol diri terhadap anak usia 9-11 tahun yang memiliki tingkat internet gaming disorder yang tinggi. Temuan yang dihasilkan dari rangkaian penelitian ini 
menunjukkan bahwa terdapat pengaruh yang signifikan dari pemberian perlakuan berupa pelatihan kontrol diri terhadap kelompok eksperimen. Melalui metode pelatihan kontrol diri ini diharapkan anak mampu mengurangi tingkat internet gaming disorder sehingga anak terhindar dari dampak yang ditimbulkan dari penggunaan game internet yang berlebihan. Implikasi dari penelitian ini meliputi bagi orangtua, diharapkan untuk selalu mendampingi anak dalam menggunakan perangkat elektronik dan internet khususnya untuk bermain video game serta memberikan batasan waktu dalam menggunakannya agar anak terhindar dari dampak negatif yang ditimbulkan. Orangtua juga dapat memberikan alternatif permainan yang melibatkan aktivitas fisik agar anak dapat mengalihkan penggunaan game internet yang berlebihan seperti engklek, bersepeda, dan sepak bola bersama teman di sekitar rumah. Peneliti selanjutnya, disarankan dalam pembagian kelompok eksperimen dan kelompok kontrol yang dilakukan secara acak atau random assigment, selain itu peneliti dapat melakukan penelitian diberbagai daerah lainnya agar tidak terbatas di daerah Malang, sehingga metode ini dapat menjadi acuan mengurangi internet gaming disorder.

\section{REFERENSI}

Afiatin, T., Sonjaya, J. A., \& Pertiwi, Y. G. (2013). Mudah \& sukses menyelenggarakan pelatihan, melejitkan potensi diri. Yogyakarta: Kanisius

American Psychiatric Association. (2013). Diagnostic and statistical manual of mental disorders (5th ed.). Arlington, VA: American Psychiatric Association.

Arikunto, S. (2002). Prosedur penelitian suatu pendekatan praktik. Jakarta: Rineka Cipta.

Bargeron, A. H., \& Hormes, J. M. (2016). Psychososial correlates of internet gaming disorder: Psychopatology, life satisfaction, and impulsivity. Journal of Computers in Human Behavior, 68, 388-394.

Chaplin, J. P. (2006). Kamus lengkap psikologi. Jakarta : PT. Raja Grafindo.

Edralin, D. M. (2004). Training : a Strategic HRM Fuction. Retrieved Maret 21, 2018, from www.dlsu.edu.ph

Gentile, D. (2009). Pathological video-game use among youth ages 8 to 18: A national study. Journal of Psychological Science, 20, 594-602. Retrieved February 27, 2018, from doi:10.1111/psci.2009.20.issue-5

Ghufron, M. N., \& Risnawita, R. (2010). Teori-teori psikologi. Jogjakarta : AR-Ruzz Media.

Griffiths, M. D., \& Pontes, H. M. (2015). Addiction and entertainment products. In R. Nakatsu, M. Rauterberg, \& P. Ciancarini (Eds.), Handbook of digital games and entertainment technologies (pp. 1-22). Singapore: Springer. 
Griffiths, M. D., \& Wood, R. (2000). Risk factor in adolescence: The case of gambling, videogame playing, and the internet. Journal of Gambling Studies, 16, 199-225.

Iswidharmanjaya, D. (2011). Bila si kecil bermain gadget: Panduan bagi orang tua untuk memahami faktor-faktor penyebab anak kecanduan gadget. Google Book.

Iswinarti. (2017). Permainan Tradisional: Prosedur dan Analisis Manfaat Psikologis. Malang : UMM Press.

Janah, M. R. (2014). Pengaruh pelatihan kontrol diri dengan menggunakan metodetehnik gerakan mengontrol perilaku merokok (TGMPM) untuk mengurangi perilaku merokok pada siswa SMK Harapan Kartasura. Talenta Psikologi, 3, 79-99.

Khasanah, I., Prasetyo, A., \& Rakhmawati, E. (2011). Permainan tradisional sebagai media stimulasi aspek perkembangan anak usia dini. Jurnal Penelitian PAUDIA, 1(1), 91-105.

Kuss, D. J. (2013). Internet gaming addiction: Current perspectives. Psychology Research and Behavior Management, 6, 125-137.

Latipun. (2002). Psikologi eksperimen. Malang: Universitas Muhammadiyah Malang press.

Muraven, M. (2010). Building self-control strength: Practicing self-control leads to improved self-control performance. Journal of Experimental Social Psychology, $46,(2), 465-468$.

Navarona, A. I. (2016). Hubungan antara Praktek Unsafe Action dalam penggunaan gadget dengan keluhan subyektif gangguan kesehatan mata pada murid Sekolah Dasar Islam Tunas Harapan tahun 2016. Retrieved October 31, 2017, from http://mahasiswa.dinus.ac.id/

Park, J. A., Park, M. H., Shin, J. H., Li, B., Rolfe, D.T., Yoo, J. Y., Dittmore, S.W. (2016). Effect of sports participation on internet addiction mediated by selfcontrol: A case of korean adolescents. Kasetsart J. Soc. Sci., 37, 164-169.

Pebriana, P. H. (2017). Analisis penggunaan gadget terhadap kemampuan interaksi sosial pada anak usia dini. Jurnal Obsesi, 1, (1), 1-11.

Peeters, M., Koning, I., \& Eijnden, R. (2017). Predicting internet gaming disorder symptommps in young adolescents: A one-year follow-up study. Journal of Computers in Human Behavior. Retrieved Maret 2, 2018, from doi: 10.1016/j.chb.2017.008

Rho, M. J., Lee, H., Lee, T. H., Cho, H., Jung, D., Kim, D., \& Choi, I. Y. (2017). Risk factor for internet gaming disorder : Psychological factors and internet gaming characteristics. International Journal of Enviromental Research and Public Health. 
Rodriguez, A., Griffith, M. D. (2017). The treatment of internet gaming disorder: a brief overview of the PIPATIC program. Journal Mental health Addiction.

Rohmah, C. O. (2017). Pengaruh penggunaan gadget dan lingkungan belajar terhadap minat belajar siswa kelas XI kompetensi keahlian administrasi perkantoran SMK Muhammadiyah 2 Yogyakarta. Skripsi. Yogyakarta : Universitas Negeri Yogyakarta.

Santrock, J. W. (2011). Life-span development (13th ed). Jakarta : Erlangga.

Shah, N., Mathur, V. P., Kathuria, V., \& Gupta, T. (2016). Effectiveness of an educational video in improving oral health knowledge in a hospital setting. Indian Journal of Dentistry.

Simatupang, N. (2005). Bermain sebagai upaya dini menanamkan aspek sosial bagi siswa sekolah dasar. Jurnal Pendidikan Jasmani Indonesia, 3.

Sioni, S. R., Burleson, M. H., \& Bakerian, D. A. (2017). Internet gaming disorder: social phobia and identifying with your virtual self. Journal of Computers in Human Behavior, 71, 11-15.

Sugiyono. (2014). Metode penelitian pendidikan pendekatan kuantitatif, kualitatif dan $R \& D$. Bandung: Alfabeta.

Suwarto. (2010). Dimensi pengetahuan dan dimensi proses kognitif dalam pendidikan. Jurnal Pendidikan. 19,76-91.

Tangney, J. P., Baumeister, R. F., \& Boone, A. L., (2004). High self-control predicts good adjustment, less pathology, better grades, and interpersonal success. Journal of personality, 72, 271-322.

Wartberg, L., Kriston, L., Kramer, M., Schwedler, A., Lincoln, T., \& Kammerl, R. (2016). Internet gaming disorder in early adolescence: Associations with parental and adolescent mental health. European Psychiatry. Retieved Maret 2, 2018, from http://dx.doi.org/10.1016/j.eurpsy.2016.12.013

Wu, A. M., Cheung, V. I., Ku, L., Hung, E. P. (2013). Psychological risk factors of addiction to social networking sites among chinese smartphone users. Journal of Behavior Addiction, 2, 160-166.

Young, K. (2009). Understanding online gaming addiction and treatment issues for adolescents. The American Journal of Family Therapy, 37, 355-372.

Yusuf, S. (2010). Psikologi perkembangan anak dan remaja. Bandung: PT. Remaja Rosdakarya. 